\title{
Antimicrobial activity and bioactive compounds of Portuguese wild edible mushrooms methanolic extracts
}

\author{
Lillian Barros • Ricardo C. Calhelha • Josiana A. Vaz • \\ Isabel C. F. R. Ferreira • Paula Baptista • \\ Letícia M. Estevinho
}

Received: 25 March 2006 / Revised: 16 May 2006 / Accepted: 29 May 2006 / Published online: 13 June 2006

(C) Springer-Verlag 2006

\begin{abstract}
The antimicrobial properties of phenolic extracts of Portuguese wild edible mushroom species (Lactarius deliciosus, Sarcodon imbricatus and Tricholoma portentosum) against pathogens were investigated. The minimal inhibitory concentrations (MICs) were evaluated for the entire mushroom, the cap and the stipe, separately; the portion of the mushroom used proved to be influenced in the results obtained, which are directly correlated with the content of total phenols and flavonoids in the extracts. The growth of Grampositive bacteria (Bacillus cereus, B. subtilis,) was well inhibited by these mushrooms, while Escherichia coli (Gramnegative bacteria) was resistant. The study on the antifungal effect of these mushrooms revealed that Candida albicans and Cryptococcus neoformans were differently inhibited for the mushrooms used.
\end{abstract}

Keywords Wild edible mushrooms · Bioactive compounds $\cdot$ Antimicrobial activity

\section{Introduction}

Mushrooms are a nutritionally functional food and a source of physiologically beneficial medicines $[1,2]$. Both fruit-

\footnotetext{
L. Barros · R. C. Calhelha - J. A. Vaz · I. C. F. R. Ferreira ( $₫)$

P. Baptista $\cdot$ L. M. Estevinho

CIMO - Escola Superior Agrária, Instituto Politécnico de

Bragança, Campus de Sta. Apolónia,

Apartado 1172,

5301-855 Bragança, Portugal

e-mail: iferreira@ipb.pt

Tel.: + 351273303219

Fax: +351273325405

J. A. Vaz

Escola Superior de Saúde, Instituto Politécnico de Bragança,

Av. D. Afonso V,

5300-121 Bragança, Portugal
}

ing body and the mycelium contain compounds with wideranging antimicrobial activity. Mushrooms are rich sources of natural antibiotics; in these, the cell wall glucans are wellknown for their immunomodulatory properties, and many of the externalised secondary metabolites (extracellular secretions by the mycelium) combat bacteria [3, 4] and viruses [5-8]. Additionally, the exudates from mushroom mycelia are active against protozoa such as the parasite that causes malaria, Plasmodium falciparum $[9,10]$ and other microorganisms [11]. The importance of the Chinese Shiitake mushroom (Lentinus edodes) is well known; besides its antitumour activity, it has been demonstrated to increase the host resistance to bacterial and viral infections [12]. Several compounds extracted from this mushroom revealed antifungal and antibacterial activity [13, 14], namely against Staphylococcus aureus, Bacillus subtilis and Escherichia coli [15]. The chloroform and ethyl acetate extracts of the dried mushroom have antibacterial activity against Streptococcus mutans and Prevotella intermedia [16]. A few studies have been reported on the antimicrobial activity of other edible mushrooms and its bioactive compounds. Laetiporus sulphureus antioxidant and antimicrobial activities were reported and correlated to the phenols and flavonoids contents [17], and guaiane sesquiterpenoids isolated from the fruit bodies of edible lactarius species proved to have antibacterial activity [18].

The northeast of Portugal is one of the European regions with higher wild edible mushrooms diversity, some of them with great gastronomic relevance. The aim of this work was to investigate the antimicrobial properties of total polyphenols of different Portuguese wild edible mushrooms. Phenolic compounds have attracted much interest recently because in vitro and in vivo studies suggest that they have a variety of beneficial biological properties, which may play an important role in the maintenance of human health. 
Phenolics are antioxidants with redox properties, which allow them to act as reducing agents, hydrogen donors, free radical scavengers [19], and singlet oxygen quenchers [20]. They also have metal chelation properties and inhibit lipid peroxidation [21, 22]. Their significance for the human diet and antimicrobial activity has been recently established [23, 24]. Some phenolic compounds exhibit various physiological activities including anti-inflammatory, antiallergic, anticarcinogenic, antihypertensive, antiarthritic and antimicrobial activities [25].

In fact, the enhance prevalence of infectious diseases is becoming a world wide problem, and the resistance problem demands that a renewed effort should be made to seek antimicrobial agents effective against pathogenic microorganisms resistant to current treatment. Therefore, the search for new products with antimicrobial properties is a very active domain of research, and herein we suggest natural resources for that propose.

We report a screening of antibacterial activities using Gram-positive (Bacillus cereus, B. subtilis) and Gramnegative bacteria (Pseudomonas aeruginosa, Escherichia coli) and antifungal (Candida albicans, Cryptococcus neoformans) performed for three important wild edible mushroom species, Lactarius deliciosus (L.) Gray, Sarcodon imbricatus (L.) P. Karst., and Tricholoma portentosum (Fr.) Quél. from northeast of Portugal. These mushrooms are largely consumed and even commercialised in Trásos-Montes region. The entire mushroom, the cap and the stipe individually were used in order to compare their activities with bioactive compounds present in each portion.

\section{Materials and methods}

Microorganisms and culture conditions

The bacterial strains used as test organisms were Bacillus cereus CECT 148, B. subtilis CECT 498, Escherichia coli CECT 101, and Pseudomonas aeruginosa CECT 108, obtained from the Spanish type culture collection (CECT) of Valencia University. The fungi strains used were Candida albicans CECT 1394 from the same collection and Cryptococcus neoformans ESA 1, obtained in Microbiology Laboratory of Escola Superior Agrária de Bragança. Microorganisms were cultured aerobically at $37{ }^{\circ} \mathrm{C}$ in nutrient agar medium for bacteria, and at $30{ }^{\circ} \mathrm{C}$ in sabouraud dextrose agar medium for fungi (oven: Scientific 222 model, 2003). Before experimental use, cultures from solid medium were subcultivated in liquid media, incubated (orbital shaker incubator: Stuart Scientific SI50 model, 2001) and used as the source of inoculums for each experiment.
Chemicals

Gallic acid, $(+)$-chatechin and Ciocalteu's phenol reagent were from Merck. Methanol was obtained from Pronalab (Lisboa, Portugal). All other chemicals were obtained from Sigma Chemical Co. (St. Louis, USA). Water was treated in a Mili-Q water purification system (TGI Pure Water Systems, USA).

\section{Mushroom samples}

Samples of L. deliciosus (L.) Gray, S. imbricatus (L.) P. Karst., and T. portentosum (Fr.) Quél. were collected under live pine trees (Pinus sp.), in Bragança (northeast of Portugal), in autumn 2004. After collection, the mushrooms were grouped by taxon and were air-dried in a liophylizator (Ly-8-FM-ULE, Snijders) before analysis. Taxonomic identification was made according to several authors [26-30] and representative voucher specimens were deposited at the herbarium of Escola Superior Agrária of Instituto Politécnico de Bragança.

A fine dried mushroom powder (20 mesh) sample (10 g) was extracted by stirring with $100 \mathrm{ml}$ of methanol at $25^{\circ} \mathrm{C}$ at $150 \mathrm{rpm}$ for $24 \mathrm{~h}$ and filtered through Whatman $\mathrm{N}^{\circ} 4$ paper. The residue was then extracted with two additional $100 \mathrm{ml}$ portions of methanol, as described earlier. The combined methanolic extracts were evaporated at $40{ }^{\circ} \mathrm{C}$ to dryness.

For agar diffusion assays, the phenolic compounds were dissolved in DMSO and filter-sterilization through a $0.22 \mu \mathrm{m}$ membrane filter. The range of phenolic compounds concentrations used includes $500 \mathrm{mg} / \mathrm{ml}$ to $0.1 \mathrm{mg} / \mathrm{ml}$. All the assays were performed using the entire mushroom, the cap or the stipe separately.

Determination of bioactive components

Phenolic compounds in the mushroom methanolic extracts were estimated by a colorimetric assay, based on procedures described by Singleton and Rossi with some modifications [31]. Briefly, $1 \mathrm{ml}$ of sample was mixed with $1 \mathrm{ml}$ of Folin and Ciocalteu's phenol reagent. After $3 \mathrm{~min}, 1 \mathrm{ml}$ of saturated sodium carbonate solution was added to the mixture and adjusted to $10 \mathrm{ml}$ with distilled water. The reaction was kept in the dark for $90 \mathrm{~min}$, after which the absorbance was read at $725 \mathrm{~nm}$ (Analytikijena 200-2004 spectrophotometer). Gallic acid was used to calculate the standard curve $(0.01-0.4 \mathrm{mM})$. Estimation of the phenolic compounds was carried out in triplicate. The results were mean values \pm standard deviations and expressed as milligrams of gallic acid equivalents (GAEs) per gram of extract.

Flavonoid contents in the extracts were determined by a colorimetric method described by Jia et al. [32] with some 
Table 1 Extraction yield of methanolic extracts from L. deliciosus, S. imbricatus and T. portentosum

\begin{tabular}{lll}
\hline Mushroom sample & Yield $^{\mathrm{a}}(\mathrm{g})$ & Extraction\% (w/w) \\
\hline $\begin{array}{l}\text { L. deliciosus } \\
\quad \text { Total }\end{array}$ & & \\
$\quad$ Cap & 2.00 & 20.0 \\
$\quad$ Stipe & 1.43 & 14.3 \\
S. imbricatus & 1.40 & 14.0 \\
$\quad$ Total & 1.79 & \\
Cap & 1.62 & 17.9 \\
$\quad$ Stipe & 1.60 & 16.2 \\
T. portentosum & & 16.0 \\
$\quad$ Total & 1.69 & \\
Cap & 1.52 & 16.9 \\
Stipe & 1.45 & 15.2 \\
\hline
\end{tabular}

${ }^{\mathrm{a}}$ Extracted from dried mushrooms (10 g).

modifications. The mushroom extract $(250 \mu \mathrm{l})$ was mixed with $1.25 \mathrm{ml}$ of distilled water and $75 \mu \mathrm{l}$ of a $5 \% \mathrm{NaNO}_{2}$ solution. After $5 \mathrm{~min}, 150 \mu \mathrm{l}$ of a $10 \% \mathrm{AlCl}_{3} \cdot \mathrm{H}_{2} \mathrm{O}$ solution was added. After $6 \mathrm{~min}, 500 \mu \mathrm{l}$ of $1 \mathrm{M} \mathrm{NaOH}$ and $275 \mu \mathrm{l}$ of distilled water were added to the mixture. The solution was mixed well and the intensity of pink colour was measured at $510 \mathrm{~nm}$. (+)-chatechin was used to calculate the standard curve $(0.022-0.34 \mathrm{mM})$. Estimation of the flavonoid compounds was carried out in triplicate. The results were mean values \pm standard deviations and expressed as milligrams of $(+)$-chatechin equivalents (CEs) per gram of extract.

Ascorbic acid was determined according to the method of Klein and Perry [33]. The dried methanolic extract $(100 \mathrm{mg})$ was extracted with $10 \mathrm{ml}$ of $1 \%$ metaphosphoric acid for $45 \mathrm{~min}$ at room temperature and filtered through Whatman $\mathrm{N}^{\circ} 4$ filter paper. The filtrate $(1 \mathrm{ml})$ was mixed with $9 \mathrm{ml}$ of 2,6-dichloroindophenol and the absorbance was measured within $30 \mathrm{~min}$ at $515 \mathrm{~nm}$ against a blank. Content of ascorbic acid was calculated on the basis of the calibration curve of authentic l-ascorbic acid $(0.020-0.12 \mathrm{mg} / \mathrm{ml})$. The assays were carried out in triplicate; the results were mean values \pm standard deviations and expressed as milligrams of ascorbic acid per gram of extract.

$\beta$-carotene and lycopene were determined according to the method of Nagata and Yamashita [34]. The dried methanolic extract $(100 \mathrm{mg})$ was vigorously shaken with $10 \mathrm{ml}$ of acetone-hexane mixture (4:6) for $1 \mathrm{~min}$ and filtered through Whatman $\mathrm{N}^{\circ} 4$ filter paper. The absorbance of the filtrate was measured at 453, 505, 645 and $663 \mathrm{~nm}$. Content of $\beta$-carotene and lycopene was calculated according to the following equations: Lycopene $(\mathrm{mg} / 100 \mathrm{ml})=-0.0458 \mathrm{~A}_{663}$ $+0.372 \mathrm{~A}_{505}-0.0806 \mathrm{~A}_{453} ; \beta$-carotene $(\mathrm{mg} / 100 \mathrm{ml})=$ $0.216 \mathrm{~A}_{663}-0.304 \mathrm{~A}_{505}+0.452 \mathrm{~A}_{453}$. The assays were carried out in triplicate; the results were mean values \pm standard deviations and expressed as milligrams of carotenoid per gram of extract.

\section{Antimicrobial activity}

A screening of antibacterial activities with two Gramnegative (E. coli, P. aeruginosa) and two Gram-positive bacteria (B. subtilis, B. cereus) was performed; antifungal activity ( $C$. albicans, $C$. neoformans) was also assessed, and the minimal inhibitory concentrations (MICs in $\mathrm{mg} / \mathrm{ml}$ ) were determined by an adaptation of the agar streak dilution method based on radial diffusion [35, 36]. Suspensions of the microorganism were prepared to contain approximately $10^{8} \mathrm{cfu} / \mathrm{ml}$, and the plates containing agar medium were inoculated $(100 \mu \mathrm{l})$. A $50 \mu \mathrm{l}$ volume of each sample was pipetted into a hole (depth $3 \mathrm{~mm}$, diameter $4 \mathrm{~mm}$ ) made in the centre of the agar. Under the same conditions, different concentrated solutions of ampicillin (antibacterial) and cycloheximide (antifungal) in DMSO were used as standards. The MIC was considered to be the lowest concentration of the tested sample to inhibit growth of bacteria or fungi on the

Table 2 Contents of bioactive compounds found in the mushroom extracts

\begin{tabular}{llllll}
\hline Mushroom sample & Total phenols $(\mathrm{mg} / \mathrm{g})$ & Flavonoids $(\mathrm{mg} / \mathrm{g})$ & Ascorbic acid $(\mathrm{mg} / \mathrm{g})$ & $\beta$-carotene $(\mu \mathrm{g} / \mathrm{g})$ & Lycopene $(\mu \mathrm{g} / \mathrm{g})$ \\
\hline L. deliciosus & & & & & \\
$\quad$ Total & $17.25 \pm 0.65$ & $8.14 \pm 0.81$ & $0.24 \pm 0.02$ & $90.10 \pm 4.76$ & $40.71 \pm 3.45$ \\
$\quad$ Cap & $10.66 \pm 0.52$ & $4.76 \pm 0.11$ & $0.21 \pm 0.01$ & $51.00 \pm 3.12$ & $25.83 \pm 2.12$ \\
$\quad$ Stipe & $6.31 \pm 0.29$ & $3.59 \pm 0.16$ & $0.18 \pm 0.01$ & $18.50 \pm 1.25$ & $5.69 \pm 0.62$ \\
S. imbricatus & & & & & \\
$\quad$ Total & $3.76 \pm 0.11$ & $2.82 \pm 0.09$ & $0.50 \pm 0.04$ & $20.40 \pm 1.33$ & $10.51 \pm 1.00$ \\
Cap & $2.59 \pm 0.10$ & $1.72 \pm 0.08$ & $0.36 \pm 0.02$ & $12.54 \pm 1.11$ & $6.03 \pm 0.63$ \\
$\quad$ Stipe & $1.50 \pm 0.06$ & $1.46 \pm 0.08$ & $0.19 \pm 0.01$ & $7.84 \pm 0.75$ & $4.48 \pm 0.60$ \\
T. portentosum & & & & & - \\
$\quad$ Total & $10.80 \pm 0.47$ & $0.40 \pm 0.02$ & $0.52 \pm 0.04$ & - & - \\
$\quad$ Cap & $6.57 \pm 0.31$ & - & $0.31 \pm 0.02$ & - & - \\
$\quad$ Stipe & $3.91 \pm 0.17$ & - & $0.22 \pm 0.02$ & & - \\
\hline
\end{tabular}

Note. Each value is expressed as mean \pm standard deviation $(n=3) ;(-)$ Not detected. 


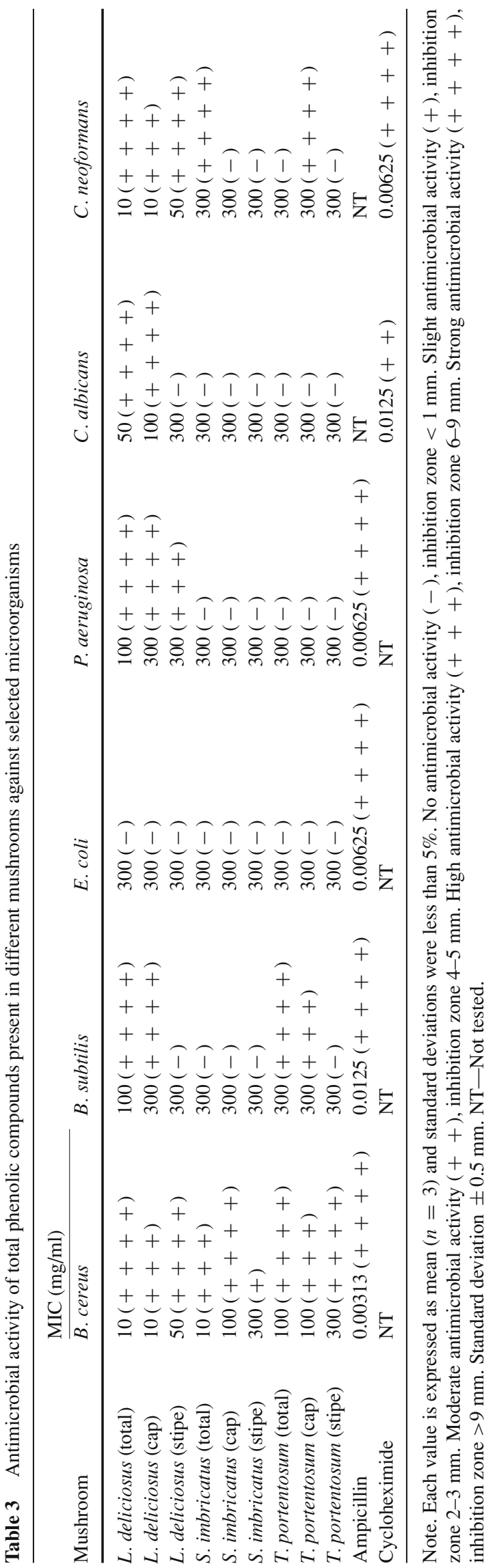

plate, after $24 \mathrm{~h}$. The diameters of the inhibition zones corresponding to the MICs were measured in millimeters with an accuracy of $0.5 \mathrm{~mm}$ using a ruler. Each inhibition zone diameter was measured three times (three different plates) and the average was taken; standard deviations were less than 5\%. Positive control using only inoculation and negative control using only DMSO in the hole were also carried out.

\section{Results}

Three wild edible mushroom species (L. deliciosus, S. imbricatus, T. portentosum) from the northeast of Portugal were evaluated for their content in total phenols, flavonoids, ascorbic acid, $\beta$-carotene and lycopene, and the obtained extracts were screened for their antimicrobial activity. The assays were carried out using the DMSO solutions of the entire mushroom, the cap and the stipe separately. DMSO was chosen as solvent after comparative toxicity assays (data not shown) and was not toxic.

We present in Table 1 the yields from mushrooms extractions. The yields of extraction with methanol were in the range of 14-20\%, and always higher when we used the entire mushroom.

Table 2 shows the concentrations of the bioactive compounds found in the mushroom extracts. Whereas total phenols and flavonoids were the major components found in the mushroom extracts, ascorbic acid was found in small amounts $(0.18-0.52 \mathrm{mg} / \mathrm{g})$, and $\beta$-carotene and lycopene were only found in vestigial amounts $(<91 \mu \mathrm{g} / \mathrm{g})$.

The portion of the mushroom used (entire, cap or stipe) had influence in the results obtained. The extracts with the entire mushroom showed higher phenolic and flavonoid contents either than the cap or the stipe. Also the amount of phenolic and flavonoid compounds in the cap methanolic extracts was higher than the amount found in stipe extracts.

The content of total phenols in the mushrooms extracts might account for the different results found in their antimicrobial activity. Table 3 shows the antimicrobial screening of phenolic compounds extracted from L. deliciosus, S. imbricatus and $T$. portentosum against $B$. cereus, $B$. subtilis $(\mathrm{Gram}+)$, E. coli, P. aeruginosa $(\mathrm{Gram}-)$ bacteria, and $C$. albicans and $C$. neoformans (fungi). The MICs for bacteria and fungi were determined as an evaluation of the antimicrobial activity of the tested mushrooms. The diameters of the inhibition zones corresponding to the MICs are also presented.

All the mushrooms revealed antimicrobial activity showing different selectivity and MICs for each microorganism (Fig. 1). L. deliciosus showed better results than T. portentosum and S. imbricatus (lower MICs), which is in agreement with the higher content of phenols and flavonoids found in 
Fig. 1 Antimicrobial activity of total phenolic compounds present in different mushrooms against selected

microorganisms. a L. deliciosus, b $S$. imbricatus and $\mathbf{c} T$.

portentosum. ( $\square$ ) concentration of $300 \mathrm{mg} / \mathrm{ml}, \square$ concentration of $100 \mathrm{mg} / \mathrm{ml},(\square)$ concentration of $50 \mathrm{mg} / \mathrm{ml}$ and $\square$ concentration of $10 \mathrm{mg} / \mathrm{ml}$
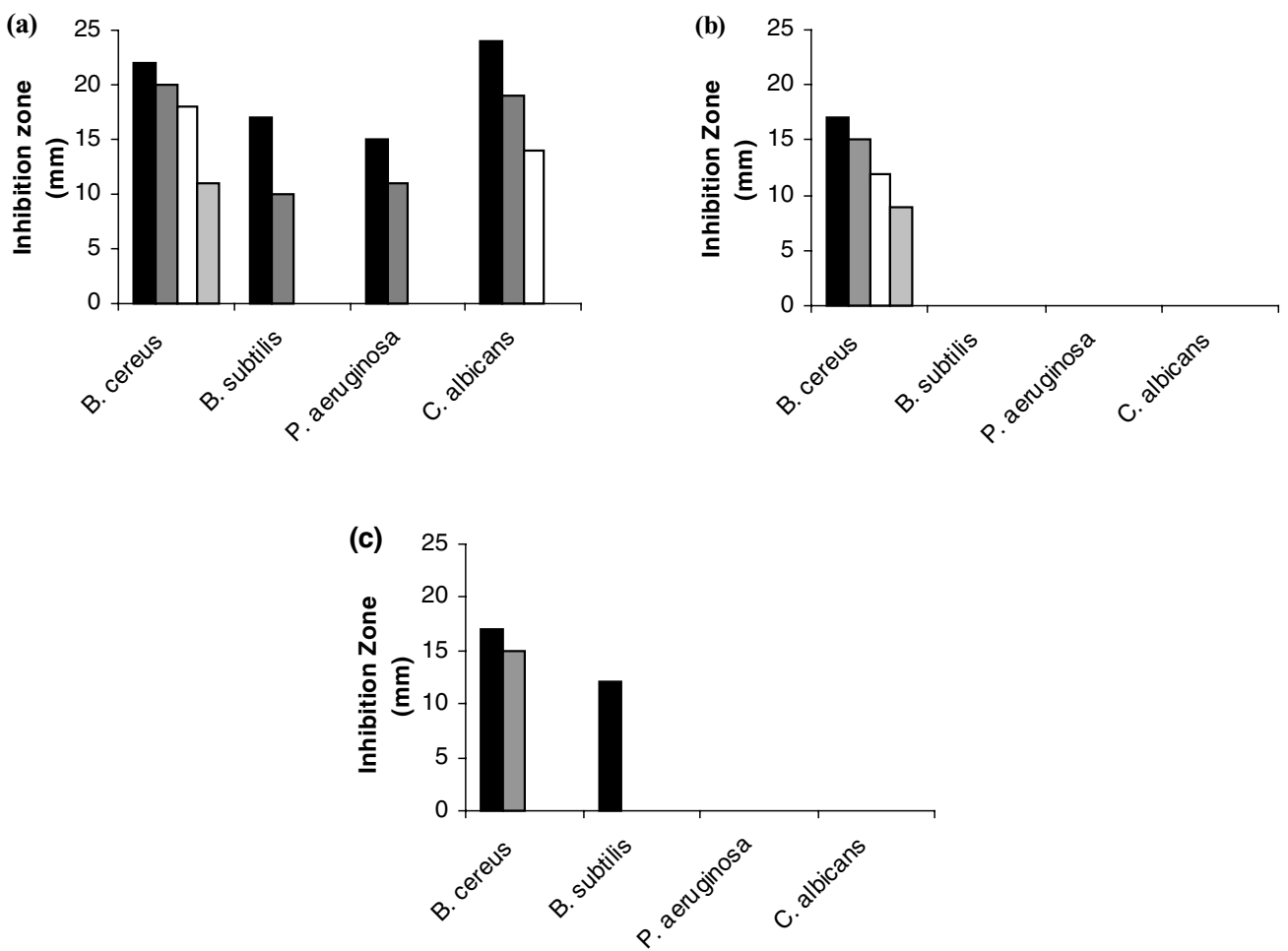

the first species (Table 2). The entire and the cap mushroom extracts inhibited $B$. cereus, $B$. subtilis, $P$. aeruginosa, $C$. albicans and $C$. neoformans, while the stipe mushroom extract only inhibited B. cereus, $P$. aeruginosa and $C$. neoformans. Only this mushroom revealed activity against $P$. aeruginosa (Gram- bacteria) and C. albicans (fungi), and for the Gram + bacteria showed lower MICs. The T. portentosum extract was effective only against Gram + bacteria (B. cereus, B. subtilis) and C. neoformans. When the cap was used the same selectivity was obtained, but with higher MICs; the stipe extract was only effective against $B$. cereus. In fact, the content in total phenols and flavonoids for the stipe extracts was always lower than in the other extracts. As expected due to its lower content in bioactive compounds, $S$. imbricatus was the less effective (higher MICs) mushroom, showing activity only against $B$. cereus and $C$. neoformans. The cap extract was selective for B. cereus, while the sipe extract was not effective against the tested microorganisms.

E. coli was resistant to all the mushrooms extracts. As expected, the standards ampiciline (antibacterial) and cycloheximide (antifungal) presented lower MICs than the mushrooms extracts. Usually, pure active compounds reveal more activity than crude extracts. Searching wild sources may bring new natural products with antimicrobial properties that provide good protection against the infectious diseases. Therefore, new wild edible mushrooms, as natural sources, could be introduced for this purpose.
On the basis of the above findings, it is concluded that the antimicrobial activity is direct correlated with the content in total phenols and flavonoids. The use of the entire mushroom is recommended and the mushroom cap proved to be better than the stipe. The extracts of L. deliciosus, S. imbricatus and T. portentosum inhibited some medically important microorganisms. This suggests that they are potential sources of new antimicrobial agents. With an increasing number of bacteria developing resistance to commercial antibiotics, such as MSRA (methicillin-resistant S. aureus and Pseudomonas), extracts and derivatives from mushrooms hold great promise for novel medicines in modern times. As far as our literature survey could ascertain, a few information was available on the in vitro antimicrobial activities of European wild mushrooms and it is the first time that Portuguese wild edible mushrooms (entire, cap and stipe) were submitted to these studies.

Acknowledgements We thank the Foundation for Science and Technology (Portugal) for financial support through CIMO - ESABragança and through project POCI/AGR/56661/2004.

\section{References}

1. Sagakami H, Aohi T, Simpson A, Tanuma S (1991) Anticancer Res 11:993-1000

2. Wasser SP, Weis, AL (1999) Int J Med Mushrooms 1:31-62

3. Benedict RG, Brady LR (1972) J Pharmacol Sci 61:1820-1822

4. Kupra J, Anke T, Oberwinkler G, Schramn G, Steglich W (1979) J Antibiotics 32:130-135 
5. Suzuki H, Iiyama K, Yoshida O, Yamazaki S, Yamamoto N, Toda S (1990) Agric Biol Chem 54:479-487

6. Collins RA, Ng TB (1997) Life Sci 60:383-387

7. Eo SK, Kim YS, Lee CK, Han SS (1999) J Ethnopharmacol 68:129-136

8. Brandt CR, Piraino F (2000) Recent Res Dev Antimicrob Agents Chemother 4:11-26

9. Lovy A, Knowles B, Labbe R, Nolan L (1999) J Herbs Spices Med Plants 6:49-57

10. Isaka M, Tantichareon M, Kongsaeree P, Thebtaranonth Y (2001) J Org Chem 66:4803-4808

11. Anke T (1989) Prog Ind Microbiol 27:51-66

12. Jong SC, Birmingham JM (1993) Adv Appl Microbiol 39:153184

13. Morita K, Kobayashi S (1967) Chem Pharmac Bull 15:988-993

14. Yasumoto K, Iwami K, Mitsuda H (1971) Agric Biol Chem 35:2059-2069

15. Takazawa H, Tajima F, Miyashita C (1982) Yakugaku Zasshi 102:489-491

16. Hirasawa M, Shouji N, Neta T, Fukushima K, Takada K (1999) Int J Antimicrob Agents 11:151-157

17. Turkoglu MA, Duru ME, Mercan N, Kivrak I, Gezer K (2006) Food Chem (in press)

18. Anke H, Bergendorff O, Sterner O (1989) Food Chem Toxicol 27:393-397

19. Ferreira ICFR, Baptista P, Vilas-Boas M, Barros L (2006) Food Chem (in press)

20. Pietta P-G (2000) J Nat Prod 63:1035-1042

21. Rice-Evans CA, Miller NJ, Paganga G (1997) Trends Plant Sci $2: 152-159$
22. Kähkönen MP, Hopia AI, Heikki JV, Rauha J-P, Pihlaja K, Kujala TS (1999) J Agric Food Chem 47:3954-3962

23. Rauha J-P, Remes S, Heinonen M, Hopia A, Kähkönen M, Kujala T (2000) Int J Food Microbiol 56:3-12

24. Nychas G-JE, Tassou CC, Skandamis P (2003) Antimicrobials from herbs and spices. In: Roller S (ed) Natural antimicrobials for the minimal processing of foods. Woodhead Publishing, Cambridge, pp 176-200

25. Vaquero MJR, Alberto MR, Nadra MCM (2005) Food Control (in press)

26. Marchand A (1971-1986) In: Champignons du Nord et du Midi, Tome 1-9. Soc Mycol Pyrénées Mediterranéenes, Perpignan

27. Moser M (1983) Keys to Agarics and Boleti (Polyporales, Boletales, Agaricales, Russulales). Roger Phillips, London

28. Bon M (1988) Guia de campo de los Hongos de Europa. Ediciones Omega, Barcelona

29. Courtecuisse R, Duhem B (1995) Mushrooms and Toadstools of Britain and Europe. HarperCollins, London

30. Courtecuisse R (1999) Mushrooms of Britain and Europe. HarperCollins, London

31. Singleton VL, Rossi JA Jr (1965) Am J Enol Vitic 16:144-158

32. Jia Z, Tang M, Wu J (1999) Food Chem 64:555-559

33. Klein BP, Perry AK (1982) J Food Sci 47:941-945

34. Nagata M, Yamashita I (1992) Nippon Shokuhin Kogyo Gakkaish 39:925-928

35. Hawkey PM, Lewis DA (1994) Medical bacterology - A practical approach. Oxford University, UK, pp 181-194

36. Ferreira ICFR, Calhelha RC, Estevinho LM, Queiroz M-JRP (2004) Bioorg Med Chem Lett 14:5831-5833 